\title{
Epigenetic Silencing of a Proapoptotic Cell Adhesion Molecule, the Immunoglobulin Superfamily Member IGSF4, by Promoter CpG Methylation Protects Hodgkin Lymphoma Cells from Apoptosis
}

Paul G. Murray, ${ }^{*}$ Yichao Fan, ${ }^{\dagger}$ Gillian Davies, ${ }^{*}$ Jianming Ying, ${ }^{\dagger \neq \S}$ Hua Geng, ${ }^{\dagger} \mathrm{Ka}$ Man $\mathrm{Ng},{ }^{\dagger}$ Hongyu Li, ${ }^{\text {}}{ }^{\circ}$ Zifen Gao, ${ }^{\text {"T }}$ Wenbin Wei, ${ }^{*}$

Shikha Bose, ${ }^{*}$ Jennifer Anderton, ${ }^{*}$ Georgia Kapatai, ${ }^{*}$ Gary Reynolds, ${ }^{*}$ Akihiko Ito," Teresa Marafioti, ${ }^{* *}$ Ciaran BJ Woodman, ${ }^{*}$ Richard Ambinder, ${ }^{\ddagger,+\dagger}$ and Qian Tao ${ }^{\dagger \ddagger, \dagger \dagger}$

\begin{abstract}
From the Cancer Research UK Institute for Cancer Studies," University of Birmingham, Birmingham, United Kingdom; the State Key Laboratory in Oncology in South China/Cancer Epigenetics Laboratory, ${ }^{\dagger}$ Sir YK Pao Center for Cancer, the Department of Clinical Oncology, Hong Kong Cancer Institute and Li Ka Shing Institute of Health Sciences, Chinese University of Hong Kong, Hong Kong; Johns Hopkins Singapore, ${ }^{\ddagger}$ Singapore; the Department of Pathology, ${ }^{\S}$ Cancer Hospital \& Cancer Institute, Peking Union Medical College, Chinese Academy of Medical Sciences, Beijing, China; the Department of Pathology, ${ }^{\mathrm{T}}$ Peking University Health Science Center, Beijing, China; the Division of Surgical Pathology," Kobe University Graduate School of Medicine, Kobe, Japan; the Department of Pathology,** University College London, London, United Kingdom; and the Sydney Kimmel Comprehensive Cancer Center, ${ }^{\dagger+}$ Johns Hopkins School of Medicine, Baltimore, Maryland
\end{abstract}

The malignant Hodgkin/Reed-Sternberg (HRS) cells of Hodgkin lymphoma (HL) are believed to derive from germinal center (GC) B cells, but lack expression of a functional $\mathrm{B}$ cell receptor. As apoptosis is the normal fate of B-cell receptor-negative GC B cells, mechanisms that abrogate apoptosis are thus critical in HL development, such as epigenetic disruption of certain pro-apoptotic cancer genes including tumor suppressor genes. Identifying methylated genes elucidates oncogenic mechanisms and provides valuable biomarkers; therefore, we performed a chemical epigenetic screening for methylated genes in HL through pharmacological demethylation and expression profiling. IGSF4/CADM1/TSLC1, a pro-apoptotic cell adhesion molecule of the immunoglobulin superfamily, was identified together with other methylated targets. In contrast to its expression in normal GC B cells, IGSF4 was down-regulated and methylated in $\mathrm{HL}$ cell lines, most primary HL, and microdissected HRS cells of $3 / 5$ cases, but not in normal peripheral blood mononuclear cells and seldom in normal lymph nodes. We also detected IGSF4 methylation in sera of 14/18 (78\%) HL patients but seldom in normal sera. Ectopic IGSF4 expression decreased HL cells survival and increased their sensitivity to apoptosis. IGSF4 induction that normally follows heat shock stress treatment was also abrogated in methylated lymphoma cells. Thus, our data demonstrate that IGSF4 silencing by CpG methylation provides an anti-apoptotic signal to HRS cells important in HL pathogenesis. (Am J Pathol 2010, 177:1480-1490; DOI: 10.2353/ajpath.2010.100052)

Hodgkin lymphoma (HL) is a tumor derived from the germinal center (GC) or the post-GC stages of $B$ cell differentiation, and is unusual among the $\mathrm{B}$ cell lymphomas in that the malignant Hodgkin/Reed-Sternberg (HRS) cells lack a functional B-cell receptor (BCR). Because apoptosis is the normal fate of BCR-negative GC B cells, mechanisms that abrogate apoptosis are likely to be critical in the development of HL. ${ }^{1}$ Such mechanisms might be expected to include the disruption of cancer genes with pro-apoptotic activity like tumor suppressor genes (TSGs). ${ }^{2}$

Supported by the Leukemia Research Fund UK, Cancer Research UK, Johns Hopkins Singapore (A*STAR grant) and the Chinese University of Hong Kong.

Accepted for publication May 11, 2010.

Supplemental material for this article can be found on http://ajp. amjpathol.org

Address reprint requests to Dr. Qian Tao, Rm 315, Cancer Center, Department of Clinical Oncology, PWH, Chinese University of Hong Kong, Hong Kong, or Dr. Paul G. Murray, Cancer Research UK Institute for Cancer Studies, University of Birmingham, Birmingham, UK. E-mail: qtao@clo.cuhk.edu.hk or p.g.murray@bham.ac.uk. 
Epigenetic silencing of TSGs has been shown to be a frequent and critical cause involved in tumor pathogenesis, ${ }^{3,4}$ including hematological malignancies though they are commonly driven by genetic mutations like chromosomal translocations. ${ }^{5}$ To identify critical TSGs aberrantly methylated/silenced in $\mathrm{HL}$ cells, we used a chemical epigenetic approach ${ }^{6-9}$ through pharmacological demethylation of $\mathrm{HL}$ cells using 5-aza-2'-deoxycytidine (Aza) followed by genome-wide microarray expression profiling. This analysis identified a group of candidate TSGs including IGSF4 (also known as TSLC1, CADM1, SynCAM1, necl-2, RA175, Sg/GSF). IGSF4 encodes a transmembrane protein whose extracellular domain shows close homology to the immunoglobulin superfamily cell adhesion molecules (Ig-CAM), particularly with the neural cell adhesion molecules, N-CAM1 and N-CAM2, ${ }^{10}$ and the prostate tumor-suppressor TSLL2/IGSF4C. ${ }^{11} \mathrm{Si}$ lencing of IGSF $4,{ }^{12}$ is frequently observed in solid tumors including lung, ${ }^{13}$ prostate, ${ }^{10}$ pancreatic, gastric, breast, nasopharyngeal, ${ }^{14}$ and cervical cancers, ${ }^{15,16}$ as well as nasal NK/T-cell lymphoma. ${ }^{17}$ Restoration of IGSF4 expression decreases epithelial cell scattering and tubulogenesis and suppresses lung cancer metastasis in nude mice, ${ }^{13,18-20}$ IGSF4 also reduces the anchorage-independent growth and tumorigenicity of cervical cancer cells. ${ }^{16}$ As cell-cell contact and cross-linking of surface immunoglobulins is important in signaling $B$ cells to death, ${ }^{21}$ changes of cell adhesion and motility mediated by loss of receptor expression like IGSF4 would result in aberrant regulation of the cell fate of GC B cells and HRS cells. ${ }^{10,20}$ Moreover, we and others have already reported that IGSF4 is indeed a stress-responsive gene capable of inducing apoptosis. ${ }^{17,22}$ Thus, we have selected IGSF4 for further study of its abnormal loss in protecting Hodgkin lymphoma cells from apoptosis.

\section{Materials and Methods}

\section{Cell Lines and Tumor Samples}

Lymphoma cell lines studied included $B L$ cell lines (BJAB, CA46, Rael, Namalwa, Raji, AG876); diffuse large B-cell lymphoma (DLBCL) cell lines (OCl-Ly1, Ly3, Ly7, Ly8, Ly18); T-cell lines (Ly13.2, Ly17); and HL cell lines: KM-H2, L428, L540, L591, HD-MY-Z, HD-LM2, L1236 (DSMZ cell collection, Braunschweig, Germany). Some nasopharyngeal and breast carcinoma cell lines and a normal immortalized but non-transformed nasopharyngeal epithelial cell line (NP69), a transformed human embryonic kidney cell line (HEK293), and a normal lymphoblastoid cell line (CCL-256.1) were used as controls. Cells were maintained in RPMI 1640 or Dulbecco's Modified Eagle's Medium containing 10\% fetal calf serum (Invitrogen, Paisley, Scotland) and 1\% streptomycin/penicillin at $37^{\circ} \mathrm{C}$ in $5 \% \mathrm{CO}_{2}{ }^{8}$ For demethylation experiments, cell lines were treated with $5 \mu \mathrm{mol} / \mathrm{L}$ of demethylating agent Aza (Sigma, St. Louis, MO), which is a cytosine analog that demethylates DNA by inhibiting DNA methyltransferase, for 3 days. ${ }^{8}$ The collection and processing of lymphoma biopsy samples used in the present study have been described previously. 2,8,23

Normal peripheral blood mononuclear cells (PBMCs), sera from healthy individuals and $\mathrm{HL}$ patients, cells microdissected from normal germinal centers, and lymph node samples taken from individuals without any malignancy, and in which histological examination revealed either normal histology or reactive hyperplasia, were collected as previously described. ${ }^{2}$ DNA and RNA were extracted from cell lines and primary tumors using TriReagent (Molecular Research Center, Cincinnati, Ohio) as previously described. ${ }^{8,23}$

\section{Microarray Expression Profiling}

$\mathrm{KM}-\mathrm{H} 2$ cells were suspended at $1 \times 10^{5} \mathrm{cells} / \mathrm{ml}$ in cRPMI-1640 and allowed to grow overnight. Aza was added to the desired concentrations ( $5 \mu \mathrm{mol} / \mathrm{L}$, dissolved in $\mathrm{H}_{2} \mathrm{O}$ ), with distilled $\mathrm{H}_{2} \mathrm{O}$ instead of drug as the control. Cells were treated for 3 days, with fresh medium containing Aza replaced every 24 hours. After the treatment, cells were pelleted and washed with PBS, and DNA and RNA were extracted. Affymetrix Human Genome Focus Arrays (Affymetrix, Santa Clara, CA) were used for all experiments. Total RNA was used to prepare biotinylated RNA as indicated by manufacturer protocol (Affymetrix, Santa Clara, CA). The $3^{\prime} / 5^{\prime}$ ratios for glyceraldehyde-3phosphate dehydrogenase (GAPDH) and $\beta$-actin were within acceptable limits (GAPDH 0.74 to $0.87, \beta$-actin 0.80 to 1.08 ), and $B i o B$ spike controls were present on $3 / 6$ chips, with BioC, BioD, and CreX also present in increasing intensity. When scaled to a target intensity of 100 (Affymetrix MAS 5.0), scaling factors for all arrays were within acceptable limits, as were backgrounds, $Q$ values and mean intensities. Images of GeneChips were analyzed by Affymetrix Microarray Suite 5.0. Probe level quantile normalization and robust multi-array analysis ${ }^{24}$ on the raw.CEL files were performed using the Affymetrix package of the Bioconductor (htttp://www.bioconductor.org, last accessed July 29, 2010) project. Differentially expressed probe sets were identified using SAM ${ }^{25,26}$; only those with changes $\geq 1.8$-fold and false discovery rate $\leq 1 \%$ were included. Hierarchical clustering was performed using dChip (http://www.dchip.org, last accessed July 29, 2010).

\section{Semiquantitative Reverse Transcription-PCR}

For reverse transcription (RT)-PCR, total RNA and AmpliTaq Gold (PE Biosystem, Foster City, CA) were used. ${ }^{27}$ The PCR program used initial denaturation at $95^{\circ} \mathrm{C}$ for 10 minutes, followed by 35 cycles $\left(94^{\circ} \mathrm{C}\right.$ for $30 \mathrm{~s}, 55^{\circ} \mathrm{C}$ for $30 \mathrm{~s}$ and $72^{\circ} \mathrm{C}$ for $30 \mathrm{~s}$ ), with a final extension at $72^{\circ} \mathrm{C}$ for 10 minutes. ${ }^{9}$ The primers for IGSF4 were: A: $5^{\prime}$-TCCGGCTTCTGCTGTTGC-3'; B: 5'-TTTCCTGTGGGGGATCGG-3'. The signals were quantified by densitometry using the ImageJ software (http://rsbweb.nih.gov/ij/index. html) developed by Wayne Rasband (Research Services Branch, National Institute of Mental Health, Bethesda, Maryland). 

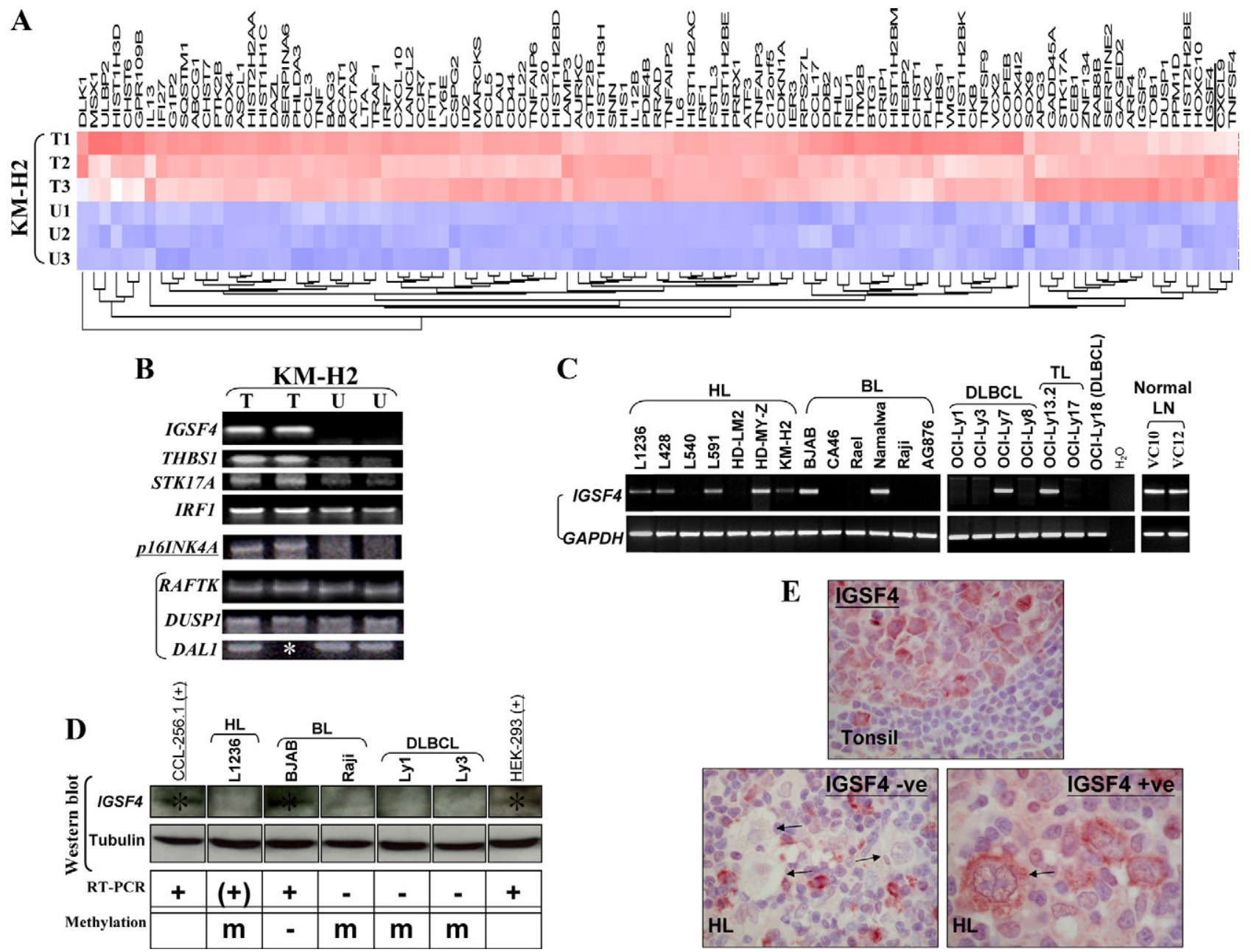

Figure 1. A: Heat map of genes up-regulated in KM-H2 cells following demethylating treatment with Aza. T1-3: treated samples; U1-3: controls. IGSF4 is underlined. B: Validation of microarray results by RT-PCR of selected genes up-regulated in KM-H2 cells after Aza treatment (T) compared with untreated cells (U). Upregulation of mRNA for IGSF4, THBS1, STK17A and IRF1, and unchanged expression of RAFTK, DUSP1, and DAL1 are shown. D16INK4A was not picked up by the microarray screening, however its expression was up-regulated after Aza treatment. Asterisk indicates that no RNA left in one sample. C: IGSF4 down-regulation in HL and NHL cell lines by RT-PCR. RT-PCR analysis showed that when compared with two normal lymph nodes, IGSF4 expression was completely lost or reduced in $6 / 7$ HL, $4 / 5$ DLBCL, and 4/6 BL cell lines. D: IGSF4 protein expression correlated with its mRNA expression, absent in methylated cell lines: one HL cell line (L1236), one BL (Raji), and two DLBCL cell lines (Ly1 and Ly3). HEK293 and CCL-256.1 were used as positive controls. Asterisk indicates the +v band for IGSF4 protein. E: Immunohistochemistry with an IGSF4-specific monoclonal antibody in normal lymphoid tissues and HL. Upper panel shows normal expression of IGSF4 protein in GC B cells. In contrast, HRS cells in most HL cases lacked expression or showed lower levels of expression. A representative example of the absence of IGSF 4 expression is shown in the lower left panel. HRS cells are indicated with arrows. A minority of cases showed normal expression of IGSF 4 in HRS cells (lower right panel). These results were confirmed using two separate chicken polyclonal antibodies directed to IGSF4 (data not shown). See Table 4 for correlation with MSP analysis.

\section{Methylation-Specific PCR and Bisulfite Genomic Sequencing}

Genomic DNA was treated with sodium metabisulfite (Sigma) as previously described, ${ }^{27}$ but without prior EcoRI digestion. Methylation-specific PCR (MSP) was performed according to our previous method and can detect $1 \%$ methylated alleles in an unmethylated DNA background. ${ }^{2}$ Primers used were as follows: for the methylated promoter (142-bp product), TSLC1m12 (5'-AGCGAGGTTTTTCGAGAGTC-3') and TSLC1m11 (5'-CCTACCTCAAACTAACGACG); for the unmethylated promoter (144-bp product), TSLC1u12 (5'-GAGTGAGGTTTTTTGAGAGTT-3') and TSLC1u11 (5'-ACCTACCTCAAACTAACAACA-3'). One ul of bisulfite-treated DNA ( 50 ng measured before bisulfite treatment) was PCR amplified using $0.3125 \mathrm{U}$ of AmpliTaq Gold (Perkin Elmer-Cetus, Norwalk, CT) with $2 \mathrm{mmol} / \mathrm{L} \mathrm{MgCl}_{2}, 0.2 \mathrm{mmol} / \mathrm{L}$ dNTP and
$0.6 \mathrm{umol} / \mathrm{L}$ each primer in a $12.5 \mu \mathrm{l}$ reaction volume. MSP was conducted with hot-start at $95^{\circ} \mathrm{C}$ for 10 minutes, then 38 cycles $\left(94^{\circ} \mathrm{C}, 30 \mathrm{~s} ; 58^{\circ} \mathrm{C}, 30 \mathrm{~s} ; 72^{\circ} \mathrm{C}, 30 \mathrm{~s}\right)$, followed by $72^{\circ} \mathrm{C}$ for 5 minutes. MSP products were analyzed on a $1.8 \%$ agarose gel. GeneRuler 100-bp Plus DNA ladder was used as a marker to indicate the size of the MSP products on the gel. MSP primers were shown not to amplify DNA not treated with bisulfite thus specific and selected MSP products were sequenced.

Bisulfite genomic sequencing (BGS) was performed as described previously. ${ }^{27}$ The strand-specific primers for the bisulfite-converted single stranded DNA of the IGSF4 promoter were: BGS3, 5'-GGATTTTTTTAAGGGAGATTTTTT-3', BGS2A, 5'-CRAACACCTACCTCAAACTAA-3'. These two primers amplify a 422-bp region with $35 \mathrm{CpG}$ sites in the IGSF4 promoter. For BGS, at least 6 to 8 bacterial colonies were analyzed for each DNA sample. 
Table 1. Thirty Known and Candidate TSGs Up-Regulated Following Aza Demethylation of KM-H2 HL Cells

\begin{tabular}{|c|c|}
\hline Gene name & Activity/tumor suppressor function \\
\hline IGSF4/CADM1/TSLC1 & Known TSG, inactivated by methylation in lung and other tumors \\
\hline CDKN1A (p21) & Known TSG, sometimes inactivated by methylation in cancers, also induced by 5 -aza- ${ }^{\mathrm{d}} \mathrm{C}$ treatment \\
\hline $\begin{array}{l}\text { CCL3 } \\
\text { CCL20 }\end{array}$ & $\begin{array}{l}\text { Expression decreases tumorigenesis in the colorectal tumor model CMT93 } 334 \\
\text { Expression decreases tumorigenesis in the colorectal tumor model CMT93 }\end{array}$ \\
\hline CD44 & $\begin{array}{l}\text { Metastasis suppressor, inactivated by methylation in several tumors, including prostate and gastric } \\
\text { cancer, neuroblastoma }\end{array}$ \\
\hline CRIP1 & Methylated and growth suppressive in esophageal squamous cell carcinoma ${ }^{7}$ \\
\hline DLK1 & Methylated and growth suppressive in neuroblastoma and renal cell carcinoma ${ }^{35}$ \\
\hline IRF1 & Known TSG ${ }^{32}$; promoter methylation not described \\
\hline IRF7 & Known TSG, inactivated by methylation in astrocytoma and hepatocellular carcinoma ${ }^{31}$ \\
\hline IER3/IEX-1 & Induces apoptosis in HeLa cells ${ }^{36}$ \\
\hline ZMAT3/WIG1 & Growth inhibitory zinc finger protein ${ }^{33}$ \\
\hline BTG-1 & Anti-proliferative function 37 \\
\hline THBS1 & Known TSG, methylated in gastric cancer, nasopharyngeal carcinoma and others ${ }^{29}$ \\
\hline FHL2/DRAL & Pro-apoptosis function ${ }^{38}$ \\
\hline DDB2 & Feline homolog implicated as TSG in B cell lymphoma ${ }^{39}$ \\
\hline LYGE/R/G-E & Down-regulation associated with development of hepatocellular carcinoma ${ }^{40}$ \\
\hline MSX1 & $\begin{array}{l}\text { Interacts with p53, overexpression induces apoptosis of cancer cells harboring nonfunctional wild-type } \\
\text { p53 and suppressed growth of human tumor xenografts in nude mice }{ }^{41}\end{array}$ \\
\hline GADD45A & Induced by 5-azacytidine, growth arrest \\
\hline HOXC10 & Degradation associated with cell cycle progression ${ }^{42}$ \\
\hline STK17A/DRAK1 & Pro-apoptosis function ${ }^{43}$ \\
\hline $\begin{array}{l}\text { KLF6/COPEB/BCD1 } \\
R R A D\end{array}$ & $\begin{array}{l}\text { Candidate TSG, mutated in some cancers (prostate and colon) } \\
\text { Methylated in malignant mesothelioma }\end{array}$ \\
\hline TOB1 & $\begin{array}{l}\text { Putative TSG, mice lacking Tob1 are predisposed to cancer development }{ }^{45} \text {, loss of expression } \\
\text { associated with lung cancer development }\end{array}$ \\
\hline SOX9 & Overexpression suppresses growth and tumorigenicity of prostate cancer cells ${ }^{46}$ \\
\hline$\angle A M P 3 / C D 63$ & Decreased expression of CD63 elevates invasive potential of human melanoma cells \\
\hline ITM2B & Candidate TSG in prostate cancer \\
\hline MARCKS & Candidate TSG in melanoma \\
\hline FSTL3 & Potential TSG. Down-regulated in endometrial cancer \\
\hline PRRX1 & Potential TSG. Inhibits transforming properties of Maf ${ }^{47}$ \\
\hline PLK2 & Cell cycle checkpoint, inhibits oncogenic transformation \\
\hline
\end{tabular}

\section{Methylation Analysis of Microdissected HRS Cells and Serum DNA by Nested-MSP}

Fifty HRS cells were microdissected from each case and DNA was extracted using the QIAamp MiniElute virus kit. The DNA was bisulfite-treated and amplified using primers TSLC1BGS7 (5'-ATGTTATTAGTATTTTATTAGTTGTT$\left.3^{\prime}\right)$ and TSLC1BGS8 (5'-CACACCTACCTATAAAAATCAATA-3') (60 cycles), using $0.625 \cup$ of AmpliTaq Gold in a $12.5 \mu \mathrm{l}$ reaction volume. Five $\mu$ l of the $10 \times$ diluted PCR products were used for a nested-MSP with methylation-specific primers TSLC1m5 and TSLC1m8 (109-bp product), TSLC1m5: 5'-TAGTATTTTATTAGTTGTTCGTTC-3', TSLC1m8: 5'-GCACACTAAAATCCGCTCG-3'; or unmethylated-specific primers TSLC1u5 and TSLC1u8 (112-bp product), TSLC1u5: 5'-TTAGTATTTTATTAGTTGTTTGTTT-3', TSLC1u8: 5'-CCACACACTAAAATCCACTCA-3'. Nested-MSP was conducted at $95^{\circ} \mathrm{C}$ for $10 \mathrm{~min}-$ utes, then 45 cycles $\left(94^{\circ} \mathrm{C}, 30 \mathrm{~s} ; 58^{\circ} \mathrm{C}, 30 \mathrm{~s} ; 72^{\circ} \mathrm{C}, 30 \mathrm{~s}\right)$, followed by $72^{\circ} \mathrm{C}$ for 5 minutes, using $0.625 \mathrm{U}$ of AmpliTaq Gold in a $12.5 \mu$ l reaction volume.

A similar approach was used to detect IGSF4 methylation in serum samples from $\mathrm{HL}$ patients, ${ }^{2}$ except that primers TSLC1m12 and m11 (40 cycles, $0.625 \mathrm{U}$ of AmpliTaq Gold in a $12.5 \mu$ l reaction) were used for the first round of PCR. One $\mu$ l of the $10 \times$ diluted PCR products was then used in a nested-MSP with the methylationspecific primers TSLC1m10 (5'-GTGATTGGTTTGTTCGGATTTC-3') and TSLC1 m11 (103-bp product, 40 cycles, $0.625 U$ of AmpliTaq Gold in a $12.5 \mu$ l reaction). For detection of unmethylated alleles in serum samples, primers TSLC1 BGS9R and BGS2A (40 cycles, $0.625 \mathrm{U}$ of AmpliTaq Gold in a $12.5 \mu$ l reaction) were used for the first round of PCR and one $\mu$ l of the $10 \times$ diluted PCR products was used in the nested-MSP with methylationspecific primers TSLC1u10 (5'-TGTGATTGGTTTGTTTGGATTTT-3') and TSLC1u11 (105-bp product, 40 cycles, $0.625 \mathrm{U}$ of AmpliTaq Gold in a $12.5 \mu$ l reaction). Nested MSP products were confirmed by direct sequencing.

\section{Phenotypic Effects of Ectopic Expression of IGSF4 in HL Cells}

Transient expression of IGSF4 in cell lines was achieved using the nucleofection system (Amaxa $\mathrm{GmbH}$ ). Briefly, $2 \times 10^{6}$ cells and $5 \mu \mathrm{g}$ of each plasmid were suspended in $100 \mu$ l of prepared Nucleofector solution kit T and pulsed using program T-01. Transfection efficiency was monitored by parallel transfection of cell lines with a GFP expression vector followed by fluorescence-activated cell sorting analysis. Transfection efficiency was $>70 \%$ for $\mathrm{HL}$ cell lines (data not shown). Viability assays (48 hours post-transfection) using Trypan blue and proliferation assays (72 hours post-transfection) using WST1 reagent (Roche Diagnostics, Lewes, UK) were performed on transiently transfected cells. The IGSF4 expression vector was kindly provided by Professor RD Steenbergen. ${ }^{16}$ The RT-PCR primers used for detection of IGSF4 transcripts were as described. ${ }^{16} \mathrm{GAPDH}$ primers were as follows: GAPDH forward 5'-CCACCCATGGCAATTCCAT- 
A
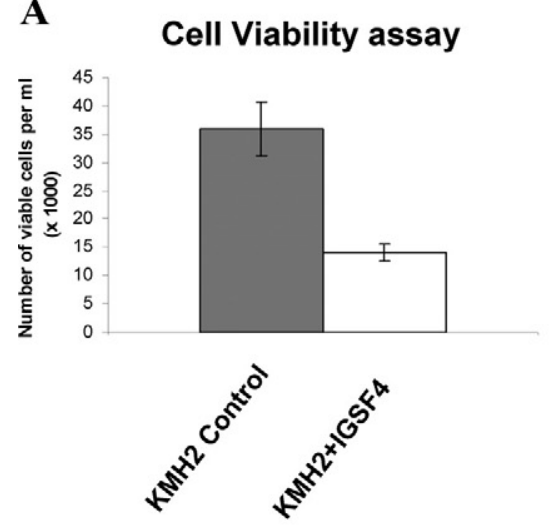

B
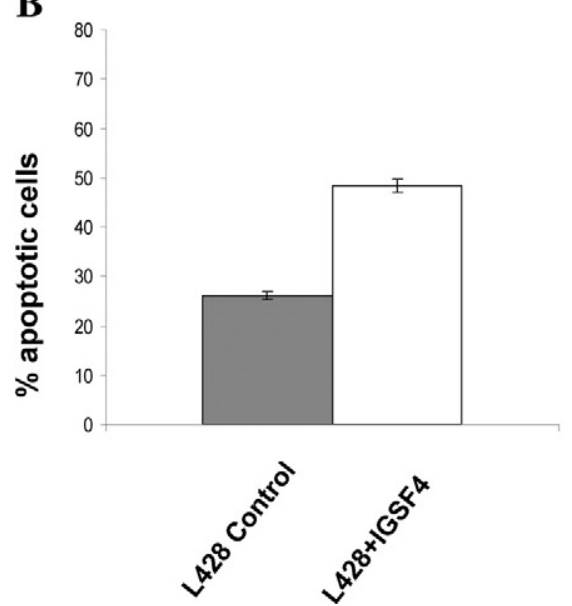

Cell Proliferation assay

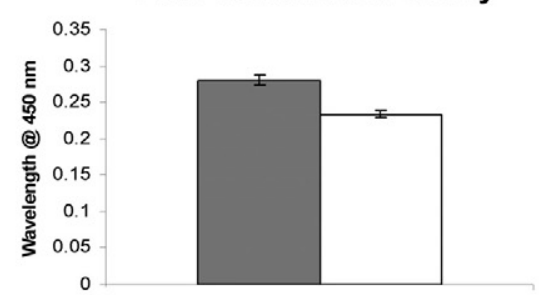

$+5^{x^{0^{2}}}+5^{x^{2}}$
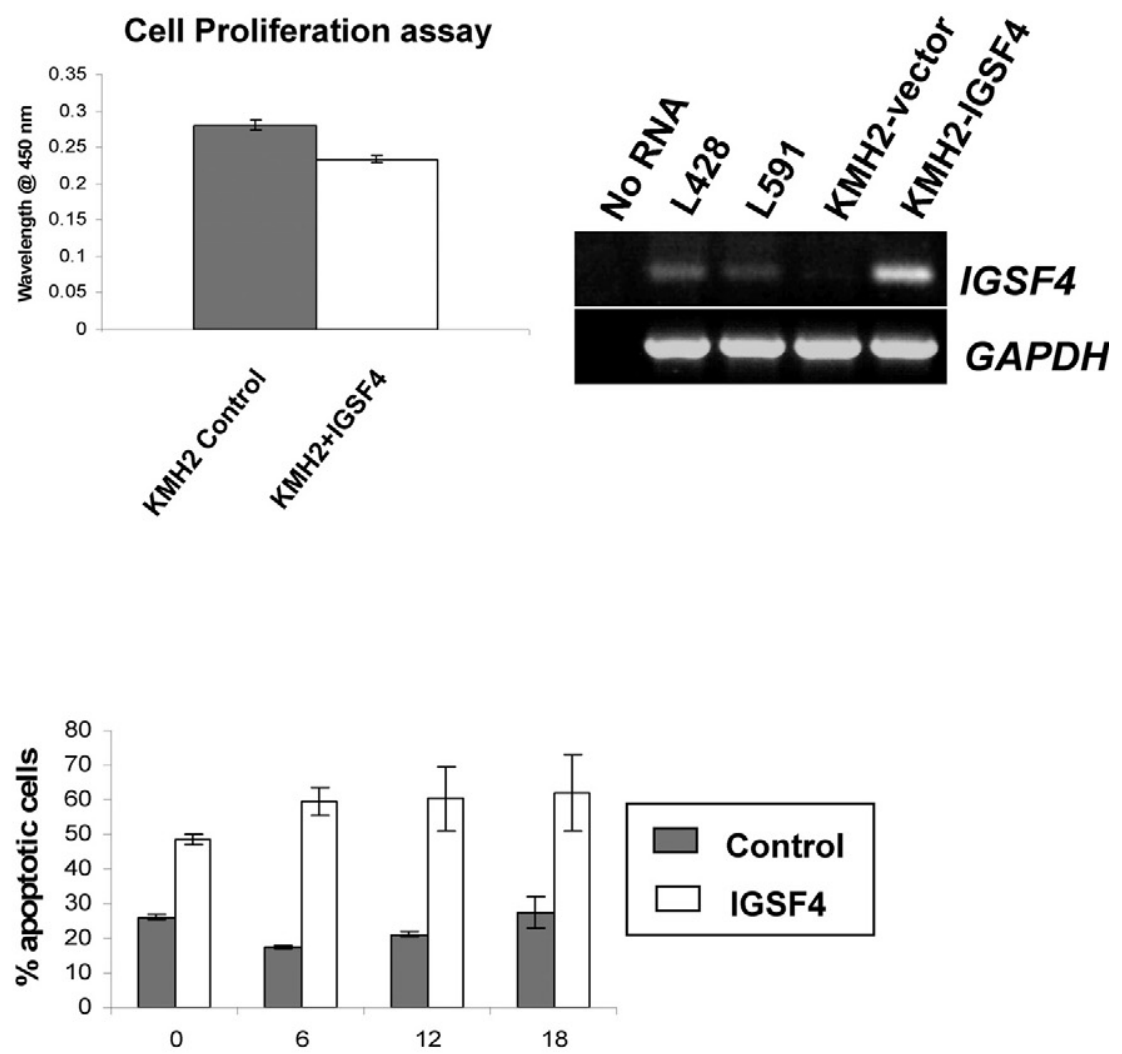

HOURS IN 5ug/mI IONOMYCIN

Figure 2. A: Representative phenotypic changes in HL cells following ectopic IGSF4 expression. KM-H2 cells with low levels of IGSF4 were transfected either with IGSF4 expression vector or empty vector. Cell proliferation was monitored by WST1 assay and cell viability was monitored by Trypan blue assay. Left panel shows reduced cell viability ( 48 hours) and proliferation ( 72 hours) following ectopic IGSF 4 expression (white bars) compared with cells transfected with vector (gray bars). Right panel shows RT-PCR analysis of the levels of IGSF4 mRNA following transfection. B: Representative data of apoptosis for L428 cells. Left panel shows increased apoptosis 48 hours after transfection with IGSF4 (white bars) compared with control (gray bars). Right panel shows percentage of apoptotic cells in untreated cells (time 0 hour) and in cells treated with the apoptosis inducer, ionomycin $(5 \mu \mathrm{g} / \mathrm{ml}$; after 6,12 and 18 hours). Ionomycin treatment increased apoptosis in IGSF4-transfected cells but not in control cells.

GGCA-3'; GAPDH reverse 5'-TCTAGACGGCAGGTCAGGTCCACC-3'. Apoptosis was determined by the standard Annexin V-PE apoptosis detection kit according to the manufacturer's instructions (BD Pharmingen Ltd) and analyzed by flow cytometry.

\section{Immunohistochemistry}

Immunohistochemistry (IHC) was performed on $4 \mu \mathrm{m}$ sections as previously described. ${ }^{2}$ We used an IGSF4specific monoclonal antibody, and two separate chicken polyclonal antibodies. ${ }^{10,20}$ IGSF4 protein expression was categorized as absent/low (defined as undetectable or staining intensity in all tumor cells lower than that in GC B cells), moderate ( $>80 \%$ of tumor cells staining less intensely than GC B cells), or normal ( $>80 \%$ of tumor cells staining similarly as GC B cells).

\section{Western Blot}

Western blot analysis was performed as previously described, ${ }^{28}$ using antibody against IGSF4 (Santa Cruz Bio- technology, CA), and antibody against tubulin from Neomarkers (Fremont, CA).

\section{Results}

\section{Identification of IGSF4 as Methylated Target Gene in HL Cells}

We used a chemical epigenetic approach by comparing gene expression profiles of $\mathrm{KM}-\mathrm{H} 2 \mathrm{HL}$ cells before and after treatment with the demethylating agent Aza, using Affymetrix microarray expression analysis. This identified a total of 106 genes that were up-regulated ( $>1.8$ fold with a false discovery rate less than $1 \%$ ) following this treatment (Figure 1A), including 30 genes with known or putative tumor suppressor functions, several of which have previously been shown to be inactivated by methylation in other tumors (Table 1), ${ }^{7,29-47}$ such as IGSF4, GADD $45 \alpha$, THBS $1,{ }^{29} C D 44,{ }^{30}$ and IRF7, ${ }^{31}$ although these genes have not been reported to be epigenetically silenced in HL. Several up-regulated genes were known 
A

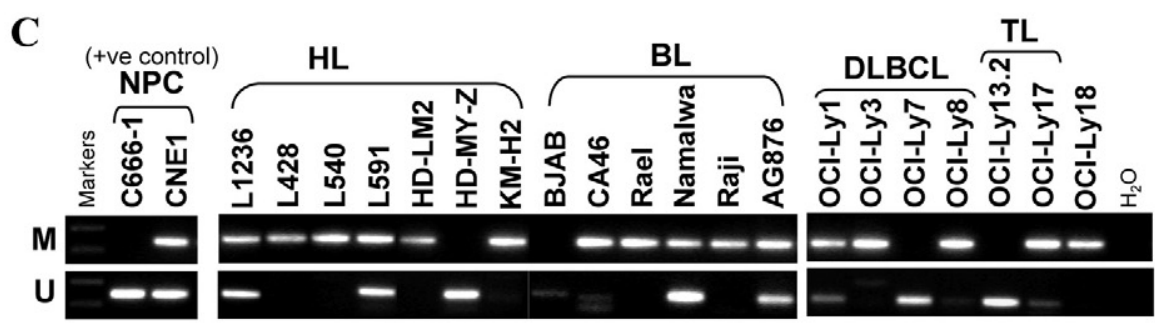

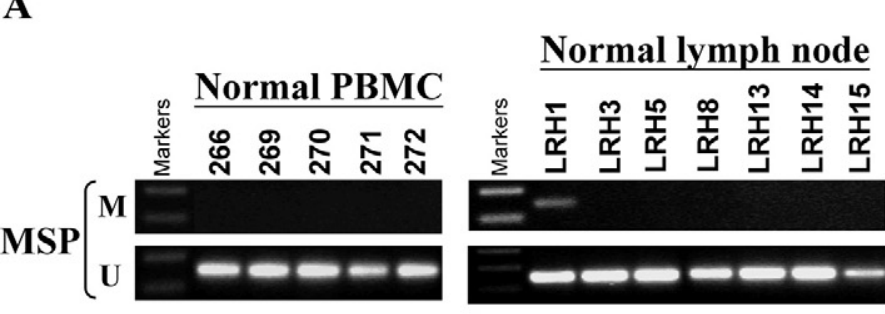

D

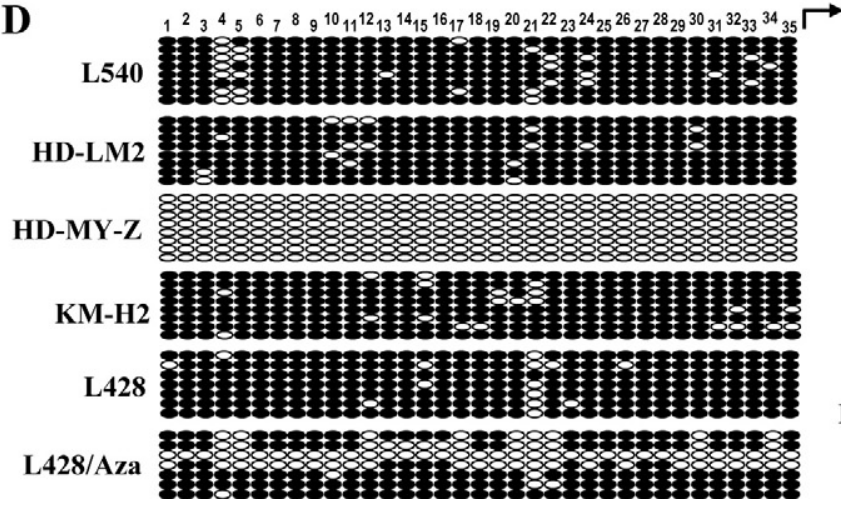

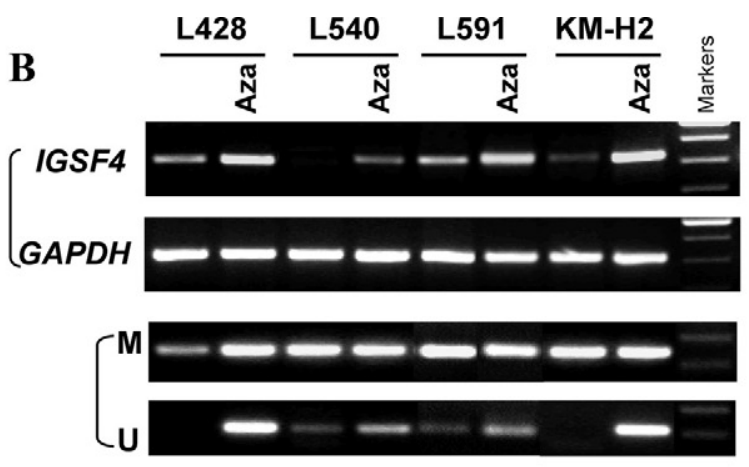

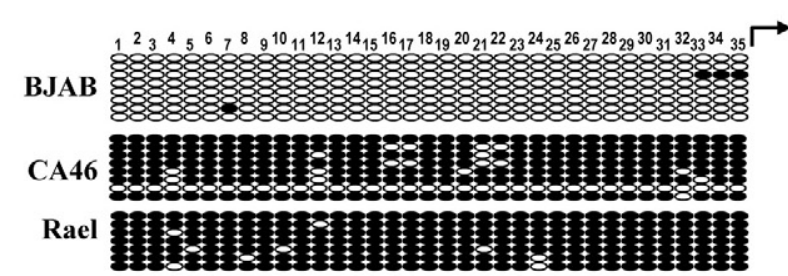

PBMCH9

PBMCH10

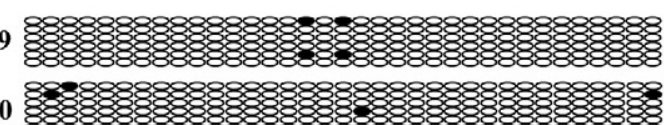

Figure 3. Analysis of IGSF4 methylation in normal PBMC, normal lymph nodes, and lymphoma cell lines. A: By MSP, all PBMC and 6/7 nonmalignant lymph node samples showed only un-methylated IGSF4 promoter; one lymph node with weak IGSF4 methylation was detected. (M = MSP for methylated DNA; U = USP for unmethylated DNA). B: Up-regulation of IGSF4 mRNA with promoter demethylation by Aza treatment in HL cell lines (L428, L591 and KM-H2) with low levels of IGSF4 and L540 lacking IGSF4 expression. Upper panel shows RT-PCR analysis and lower panel shows MSP for methylation. C: MSP analysis of tumor cell lines. Loss or reduced IGSF4 expression was always accompanied by promoter methylation. NPC cell lines used as positive controls. D: Representative BGS methylation analysis in normal PBMC and lymphoma cell lines before or after Aza treatment. CpG sites are shown on the top row as numbers. Each row of circles represents a single allele of the IGSF4 promoter analyzed. Open circles: unmethylated CpG sites, filled circles: methylated CpG sites. IGSF4 was unmethylated in normal PBMCs (H9, H10) and cell lines expressing high levels of IGSF4 (examples shown are BJAB and HD-MY-Z). In contrast, IGSF4 was almost completely methylated in silenced cell lines (L540, HD-LM2, Rael, CA46, L428 and KM-H2). Promoter of L428 was partly demethylated following Aza treatment.

tumor suppressors, including IRF1, ${ }^{32}$ p53 target gene ZMAT3/WIG1, ${ }^{33}$ and KLF6/BCD-1. ${ }^{48}$ But their inactivation by aberrant methylation has not been reported. We validated the upregulation of several of these genes including IGSF4, following treatment with Aza by RTPCR analysis, together with several genes without apparent changes in expression like RAFTK, DUSP1 and DAL1 (Figure 1B). IGSF4 was selected for further investigation on the basis of its described anti-apoptotic activities. $^{22}$

\section{Loss of IGSF4 Expression in Hodgkin Lymphoma Cells}

We then studied the expression of IGSF4 mRNA in HLderived cell lines by RT-PCR (Figure 1C). When compared with two normal lymph nodes, IGSF4 mRNA levels were found to be lower in four $\mathrm{HL}$ cell lines $(\mathrm{KM}-\mathrm{H} 2$, L428, L591, L1236), and undetectable in an additional two (HDLM2, L540) (Figure 1C). Down-regulation was not unique to $\mathrm{HL}$ cell lines because 4/6 BL cell lines and 4/5 DLBCL cell lines also lacked IGSF4 expression. We next studied IGSF4 expression in primary HL tissues using an IGSF4specific monoclonal antibody. ${ }^{49}$ We observed strong expression of IGSF4 in GC B cells of reactive lymphoid tissues (Figure 1E, upper panel), but absent or low level expression in HRS cells of 7/10 HL cases (Figure 1E, lower left panel). These results were confirmed using two separate chicken polyclonal antibodies directed to IGSF4 ${ }^{50}$ (data not shown). We conclude that IGSF4 expression is down-regulated in HRS cells in the majority of cases. We also studied the protein expression level of IGSF4 in one HL cell line (L1236), two BL cell lines (Raji and BJAB), and two DLBCL cell lines (OCl-Ly1 and OCl- 
A
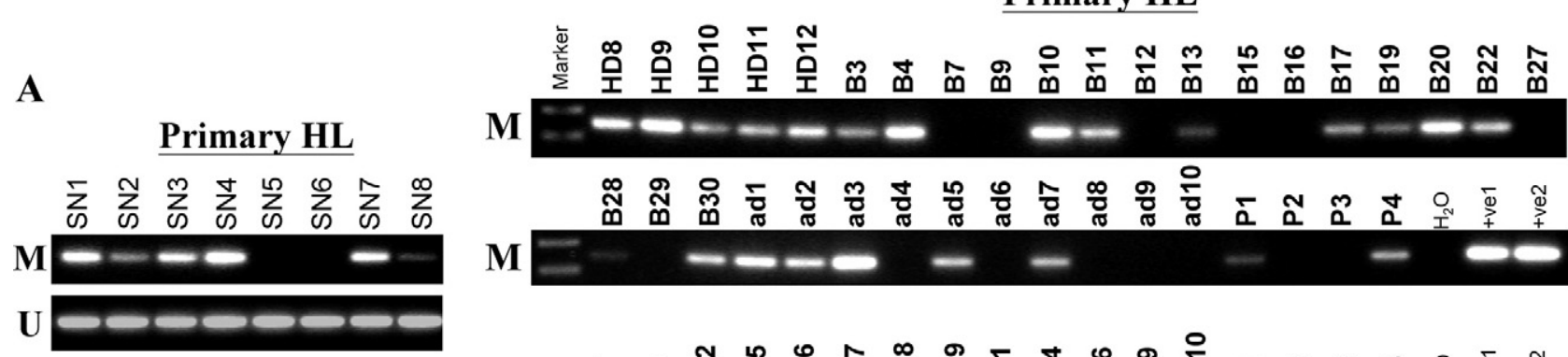

$\mathbf{M}$
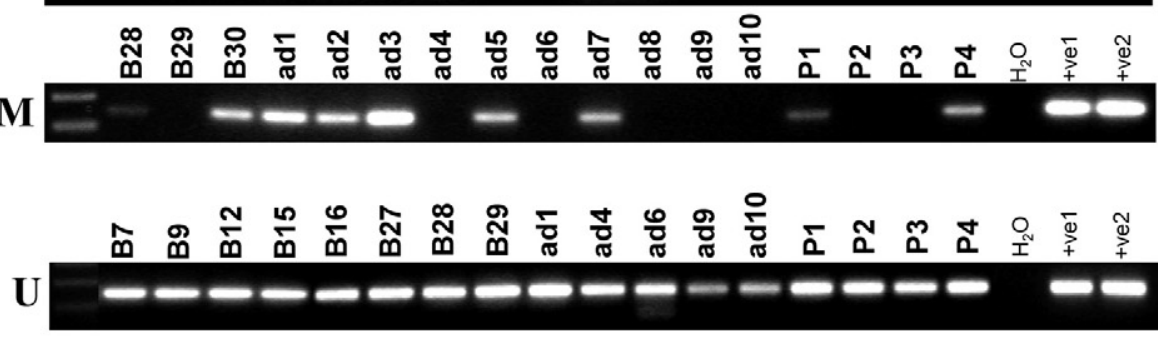

B
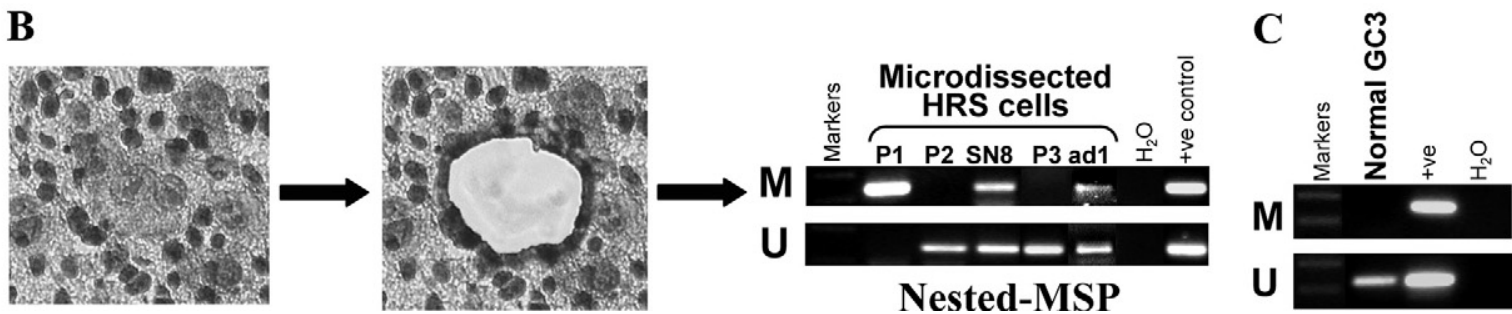

Figure 4. Analysis of IGSF4 methylation in primary HL. A: By analysis of whole tumor tissue, IGSF4 methylation was detectable in $29 / 45$ cases of HL. L591 and L1236 were used as + ve1 and + ve2 control for MSP and USP. B: Microdissection of HRS cells was performed for five HL biopsies (Table 4) following CD30 staining of HRS cells. HRS cells from three tumors (P1, SN8 and ad1) showed methylation by nested MSP analysis; all were also methylated by MSP of whole tumors (Table 2). HRS cells from two further tumors, which are unmethylated by analysis of whole tumors (P2, P3), lacked detectable IGSF4 methylation in HRS cells. L591 was used as a positive control for MSP and USP. C: IGSF4 methylation could not be detected in GC B cells microdissected from reactive lymph nodes. L591 was used as a positive control for MSP and USP.

Ly3), and detected its absence in cell lines, correlated with its RNA expression (Figure 1D).

\section{Re-Expression of IGSF4 in HL Cells Enhances Their Sensitivity to Apoptosis}

We next studied the phenotypic consequences of reexpressing IGSF4 in HL cells. KM-H2 cells were transfected with either an IGSF4-expressing vector or an empty vector as a control. When compared with control cells, ectopic IGSF4 expression led to marked reduction in cell viability and a small reduction in proliferation (Figure 2A). We next examined if IGSF4 re-expression in $\mathrm{HL}$ cells influenced their sensitivity to apoptosis. Figure $2 \mathrm{~B}$ (left panel) shows that L428 HL cells expressing exogenous IGSF4 had higher baseline levels of apoptosis, demonstrating that the reduction in survival was at least partly due to increased apoptosis. We next treated L428 cells with the apoptosis-inducing agent, ionomycin. Figure 2B (right panel) shows that compared with control cells, ionomycin treatment significantly increased apoptosis in the IGSF4-expressing HL cells. We conclude that IGSF4 expression increases the sensitivity of $\mathrm{HL}$ cells to apoptosis.

\section{Down-Regulation of IGSF4 in Hodgkin Lymphoma Is Associated with Promoter Methylation}

We next studied if methylation of the IGSF4 promoter was associated with reduced expression. MSP analysis showed no IGSF4 methylation in five PBMC samples from normal donors nor in 6/7 normal lymph node samples. One normal lymph node sample showed weak methylation (Figure 3A). In contrast, IGSF4 methylation was observed in all of the lymphoma cell lines with low or absent IGSF4 mRNA (Figure 3C). Reduced expression and promoter methylation were also accompanied by loss of IGSF4 protein in all cases (Figure 1D). To further test whether IGSF4 methylation inhibits its gene expression, $\mathrm{HL}$ cell lines were treated with demethylating agent, Aza. Following this treatment, IGSF4 transcription was induced and accompanied by an increase in unmethylated alleles of the IGSF4 promoter (Figure 3B).

We then used BGS to analyze the methylation of $\mathrm{CpG}$ islands of the IGSF4 promoter. We found that virtually all $\mathrm{CpG}$ sites in the promoter were unmethylated in normal PBMCs and in cell lines expressing high levels of IGSF4 (eg, BJAB and HD-MY-Z), but almost completely methylated in cell lines with silenced IGSF4. Following treatment with Aza, the IGSF4 promoter in the HL cell line L428 was partly demethylated, which was consistent with the MSP result (Figure 3D).

We next examined IGSF4 methylation in primary $H L$. Analysis of whole tumor extracts from $\mathrm{HL}$ biopsies showed methylation in 29/45 (64\%) cases (Figure 4A). Only two cases of lymphocyte-predominant $\mathrm{HL}$ showed methylation (2/5), in contrast to classic HL cases (27/40; Tables 2 and 3). There was no association between IGSF4 methylation and the status of Epstein-Barr virus infection of primary tumors (Table 2). IGSF4 methylation was also detected in the majority of cases of primary NHL (Table 3; Supplemental Figure 1 at $h$ ttp://ajp.amjpathol.org). 
Table 2. Histology, EBV Positivity, and IGSF4 Methylation Status of Primary HL Tumors Analyzed by MSP of Whole Tumor Sections

\begin{tabular}{|c|c|c|c|}
\hline HL case number & Histology & $\begin{array}{c}\text { EBV } \\
\text { positivity } \\
\text { (subtype) }\end{array}$ & $\begin{array}{c}\text { IGSF4 } \\
\text { methylation } \\
\text { status }\end{array}$ \\
\hline HD8 & UC & A & M \\
\hline HD9 & UC & - & M \\
\hline HD10 & UC & - & M \\
\hline HD11 & UC & - & M \\
\hline HD12 & UC & - & M \\
\hline B3 & NS & A & M \\
\hline B4 & NS & A & M \\
\hline B7 & LP & - & $U$ \\
\hline B9 & NS & $A$ & $U$ \\
\hline B10 & LD & A & M \\
\hline B11 & NS & A & M \\
\hline B12 & LP & - & $U$ \\
\hline B13 & Interfollicular & $A$ & M \\
\hline B15 & NS & - & $U$ \\
\hline B16 & NS & A & $U$ \\
\hline B17 & NS & - & M \\
\hline B19 & NS & - & M \\
\hline B20 & NS & - & M \\
\hline B22 & NS & - & M \\
\hline B27 & LP & - & $U$ \\
\hline B28 & LP & - & M \\
\hline B29 & NS & - & U \\
\hline B30 & NS & - & M \\
\hline $\operatorname{ad} 1^{*}$ & NS & - & M \\
\hline ad2 & $\mathrm{MC}$ & A & M \\
\hline ad3 & NS & - & M \\
\hline $\operatorname{ad} 4$ & NS & - & $U$ \\
\hline ad5 & $\mathrm{MC}$ & A & M \\
\hline ad6 & $\mathrm{MC}$ & A & U \\
\hline $\operatorname{ad} 7$ & LP & - & M \\
\hline ad8 & $\mathrm{MC}$ & A & $U$ \\
\hline ad9 & NS & - & U \\
\hline ad10 & NS & - & $U$ \\
\hline $\mathrm{P} 1^{*}$ & $\mathrm{MC}$ & A & M \\
\hline$P 2^{*}$ & NS & - & $U$ \\
\hline $\mathrm{P}^{*}$ & $\mathrm{MC}$ & A & U \\
\hline P4 & UC & Not Known & M \\
\hline SN1 & UC & $A+B$ & M \\
\hline SN2 & UC & A & M \\
\hline SN3 & UC & A & M \\
\hline SN4 & UC & A & M \\
\hline SN5 & UC & B & $U$ \\
\hline SN6 & UC & A & U \\
\hline SN7 & UC & A & M \\
\hline SN8* & UC & B & M \\
\hline Total: 29/45 (64.4\%) & & & \\
\hline
\end{tabular}

-, No EBV detected; A, EBV Type A; B, EBV Type B; NS, nodular sclerosis $\mathrm{HL}$; $M C$, mixed cellularity $\mathrm{HL}$; $\mathrm{LP}$, lymphocyte predominant $\mathrm{HL}$; LD, lymphocyte depletion HL; UC, classic HL, subtype not classified; $M$, methylated; $U$, unmethylated. *indicates tumors also analyzed for microdissected HRS cells (see Table 4).

We also assessed whether the IGSF4 methylation found in the analysis of whole tumors was present in HRS cells. CD30+ HRS cells were microdissected from frozen sections of five HL cases that had been analyzed by MSP of whole tumor extracts and also by IHC. Nested-MSP detected IGSF4 methylation in HRS cells in three cases in which IGSF4 methylation had been detected by MSP of whole tumor samples, but not in two MSP-negative cases (Figure 4B). No methylation was detected in GC B cells microdissected from reactive lymph nodes (Figure $4 C$ ). Sequencing of MSP products from these reactions con-
Table 3. Summary of IGSF4 Promoter Methylation (by MSP Analysis of Whole Tumors) in Primary HL and NHL

\begin{tabular}{lcc}
\hline \multicolumn{1}{c}{ Samples } & & $\begin{array}{c}\text { IGSF4 methylated } \\
\text { (no. of cases) }\end{array}$ \\
\hline HL & Classic & $27 / 40(67.5 \%)$ \\
& LP & $2 / 5(40 \%)$ \\
PTLD & & $4 / 11(36 \%)$ \\
BL & $6 / 7(86 \%)$ \\
DLBCL & $10 / 12(83 \%)$ \\
FL & $7 / 7(100 \%)$ \\
ALCL & $1 / 3(33 \%)$ \\
Mantle cell lymphoma & $4 / 4(100 \%)$ \\
\hline
\end{tabular}

LP, lymphocyte predominant HL; PTLD, post-transplant Iymphoproliferative disease; BL, Burkitt lymphoma; DLBCL, diffuse large B cell lymphoma; FL, follicular lymphoma; ALCL, anaplastic large cell (Ki$1^{+}$) lymphoma

firmed their specificity in all cases (Supplemental Figure 2 at http://ajp.amjpathol.org). The presence of unmethylated alleles in microdissected cells in most cases suggests either methylation of only one allele or the existence of subpopulations of tumor cells with differing methylation status. For all of the cases studied by either whole tumor or microdissected HRS cells, 6/7 tumors with /GSF4 methylation also showed loss of protein expression by $\mathrm{IHC}$; in contrast, of three tumors which lacked methylation only one showed reduced expression (Table 4). Thus, we conclude that methylation of the IGSF4 promoter is associated with its transcriptional repression and loss of protein expression in primary HRS cells.

\section{Promoter Methylation of IGSF4 Prevents its Induction by Stress}

Previously we showed that IGSF4 is a stress-responsive gene that can be up-regulated by heat shock and other environmental stresses in carcinoma and NK lymphoma cells. We further studied in HL cell lines, the induction of

Table 4. Correlation of IGSF4 Methylation with its Protein Expression in Primary HL

\begin{tabular}{ccc}
\hline $\begin{array}{c}\text { HL case } \\
\text { no. }\end{array}$ & $\begin{array}{c}\text { IGSF4 expression in } \\
\text { HRS cells by IHC }\end{array}$ & $\begin{array}{c}\text { Methylation status (whole } \\
\text { tumor/HRS cells) }\end{array}$ \\
\hline SN6 & Normal & $\cup$ \\
SN8* & Normal & Weak M/M \\
P3* & Moderate & $\cup / U$ \\
SN1 & Absent/low & $\mathrm{M}$ \\
SN2 & Absent/low & $\mathrm{M}$ \\
SN3 & Absent/low & $\mathrm{M}$ \\
SN4 & Absent/low & $\mathrm{M}$ \\
SN5 & Absent/low & $\mathrm{U}$ \\
SN7 & Absent/low & $\mathrm{M}$ \\
P1* & Absent/low & Weak M/M \\
ad1* & N/A & M/M \\
P2* & N/A & U/U
\end{tabular}

HRS cells were microdissected from some cases and subject to nested MSP. M, methylated IGSF4 detected; U, only unmethylated alleles detected; weak $\mathrm{M}$, predominantly unmethylated alleles, but some low level methylation detected. MSP results of either whole tumor (taken from Table 2), or microdissected HRS cells from some cases (marked by an asterisk) (see Table2). N/A-paraffin sections not available for IHC. 


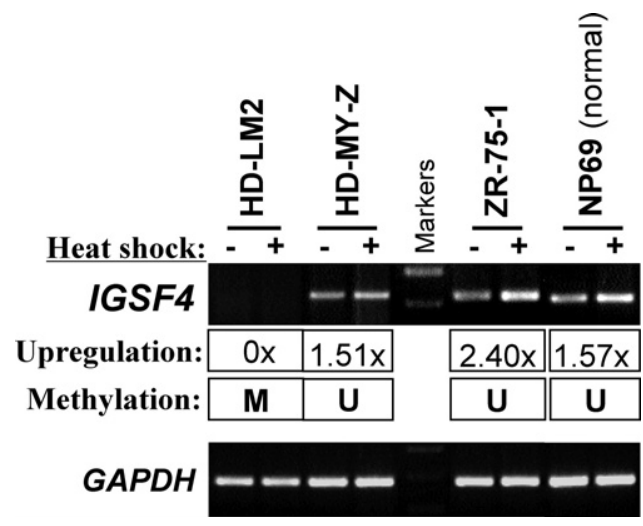

Figure 5. RT-PCR analysis of tumor cell lines shows that the response of IGSF4 to heat shock stress is impaired in methylated lymphoma cell lines. Endogenous IGSF4 mRNA expression could be up-regulated by heat shock in unmethylated cell lines, but this response was impaired when IGSF4 was silenced by promoter methylation. Shown here is the induction of IGSF4 expression following $43^{\circ} \mathrm{C}$ heat-shock treatment in tumor cell lines, HDMY-Z and ZR-75-1, but not in the HL cell line HD-LM2. NP69, a normal nasopharyngeal epithelial cell line was used as a positive control.

IGSF4 expression following heat shock treatment. We observed that in tumor cell lines with IGSF4 expression (eg, HD-MY-Z, control line ZR-751) and normal cell line (NP69), IGSF4 mRNA expression could always be upregulated following heat shock treatment (Figure 5). We also showed that this effect was not restricted to heat shock but was also observed following serum withdrawal (data not shown). In contrast, IGSF4 expression could not be induced in lymphoma cell lines with a methylated promoter (eg, HD-LM2). We conclude that in methylated cells, IGSF4 cannot be induced following their exposure to environmental stress.

\section{Frequent Detection of IGSF4 Methylation in Sera from HL Patients}

Finally, we examined IGSF4 promoter methylation in serum samples taken from 17 healthy individuals and $18 \mathrm{HL}$ patients at the time of diagnosis. Using nested-MSP, we detected IGSF4 methylation in sera of 14/18 (77.8\%) cases of $\mathrm{HL}$, but only weakly in 1/17 normal sera (Figure $6, A$ and $B$ ). ANKRD30A, a gene constitutively methylated in normal tissues, ${ }^{51}$ was used as a positive control for methylated (M) specific bands and a negative control for unmethylated (U) specific bands. MSP showed that ANKRD30A was methylated in every normal serum (albeit weakly in three samples), while only two samples showed unmethylated specific bands, indicating that our methylation analysis system is sensitive and specific. The HL serum results were confirmed by direct sequencing of the nested-MSP products (Supplemental Figure 3 at http://ajp.amjpathol.org).

\section{Discussion}

The pathogenesis of $\mathrm{HL}$ is thought to involve protection from apoptosis that would otherwise eliminate B cells lacking functional B cell receptors. Thus, genes whose inactivation might lead to protection from cell death are likely critical candidates for a pathogenic role in $\mathrm{HL}$. In this study we investigated whether IGSF4, a cell adhesion molecule of the immunoglobulin superfamily methylated in HL, could protect HRS cells from apoptosis. Although IGSF4 was originally thought to exert its tumor suppressor functions solely through changes in cell-cell interactions that facilitate metastasis, it has recently been shown to inhibit growth and proliferation of NSCLC cells through inducing their apoptosis. ${ }^{22}$

In contrast to normal GC B cells, we observed that IGSF4 expression was either lost or reduced in HRS cells in the majority of $\mathrm{HL}$ cases. Furthermore, we found that ectopic expression of IGSF4 in HL cell lines with low or absent IGSF4 expression led to their decreased survival and this was primarily a consequence of increased apoptosis. Because IGSF4 is a stress-responsive gene that can be induced by heat shock, we also investigated the effects of this treatment on the induction of IGSF4 in lymphoma cells. We observed that IGSF4 expression could only be induced by heat shock in those cell lines in which the IGSF4 gene was unmethylated and expressed, but not in cell lines where IGSF4 expression was silenced by methylation. Taken together, our results suggest that loss of IGSF4 expression may contribute to the anti-apoptotic phenotype of the HRS cell and as such may represent an important pathogenic step in the development of $\mathrm{HL}$.

We showed that the reduced expression of IGSF4 in $\mathrm{HL}$ cell lines was at least partly due to promoter methylation, and that the IGSF4 promoter was also frequently methyl-

$\mathbf{A}$

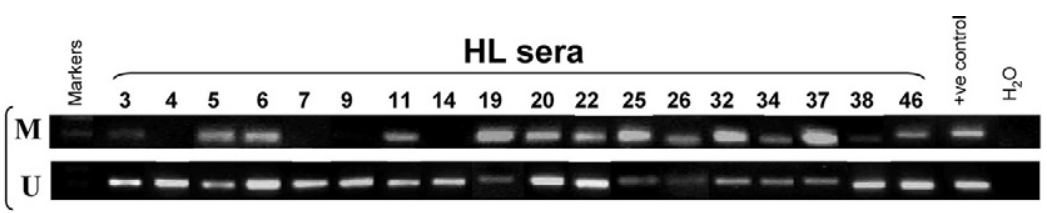

B

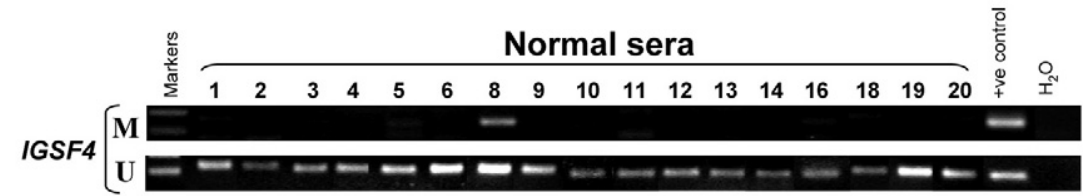

ANKRD30A $[\mathrm{M}$

(control)

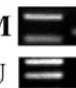

Figure 6. Analysis of IGSF4 promoter methylation in serum samples from HL patients and normal controls using nested MSP. A: IGSF4 methylation was detectable in the sera of $14 / 18$ cases of HL. L591 was used as a positive contro for MSP and USP. B: IGSF4 methylation was only detectable weakly in $1 / 17$ normal sera. MSP products were confirmed by direct sequencing (seeSupplementalFigure3at ttp://ajp.amjpathol. org). L591 was used as a positive control for MSP and USP. MSP results of ANKRD $30 A$ are shown here as a methylated positive and unmethylated negative control for normal sera. Human placenta was used as positive control for MSP and USP of ANKRD30A 
ated in primary HL. Furthermore, in primary tissues, IGSF4 methylation was localized to HRS cells where it correlated with reduced protein expression, which was in contrast to the strong expression of IGSF4 in GC B cells. Loss or reduction of IGSF4 expression has been previously demonstrated only in epithelial cancers. ${ }^{13}$ We extended our study to investigate the frequency of /GSF4 methylation in $\mathrm{NHL}$ as well as HL. Unlike another TSG we previously studied for $\mathrm{HL}-$ RASSF1A — whose methylation among hematopoietic malignancies is largely restricted to $\mathrm{HL}^{2}{ }^{2}$ we observed a high frequency of IGSF4 methylation in most forms of NHL examined, but particularly in the GC derived NHLs. Therefore, IGSF4 appears to be a key target for inactivation across a broad range of lymphomas.

A series of other putative/validated TSGs were also identified in our study, including GADD45A, THBS1, CD44, KLF6, ZMAT3/WIG1, IRF1, and 7 (Table 1). ${ }^{7,29-47}$ Although no further functional study was included in this report for these candidate TSGs, their reported functions in the pathogenesis of other types of cancers indicate that these candidates are likely also involved in the pathogenesis of HL. It should be noted that the demethylation approach also has limitations. For example, it is not possible to ascertain from the array whether the transcriptional upregulation of genes observed following Aza treatment is due to direct promoter demethylation and activation, to demethylation of regulators of the genes, or to mechanisms unrelated to methylation (eg, stress responses) $)^{52,53}$ and thus the method is prone to falsepositives. Furthermore, four TSGs previously reported to be methylated in HL: RASSF1A, ${ }^{2}$ p16INK4a, ${ }^{54}$ $\mathrm{p} 15 \mathrm{INK} 4 \mathrm{~b},{ }^{55}$ and $\mathrm{p} 18 \mathrm{INK} 4 \mathrm{c}^{56}$ were not identified in the current analysis. These "false-negatives" could be because the analysis was performed on only one cell line since p18INK4c has been reported to be unmethylated in KM-H2 cells. ${ }^{56}$ The microarray expression analysis may also have limited sensitivity, this might explain why p16/NK4a was only found to be up-regulated by Aza treatment following RT-PCR analysis. The failure to identify two genes previously reported to be methylated in $\mathrm{HL}$, RASSF1 $A^{2}$ and P14ARF (manuscript in preparation) may be because compared to other cell lines they are only minimally induced following Aza treatment.

The presence of IGSF4 methylation specifically in the serum of most HL patients suggests that it might serve as a useful biomarker for this disease. Furthermore, our observations might also have therapeutic relevance; we were able to reactivate IGSF4 expression following demethylation, suggesting that the treatment of $\mathrm{HL}$ patients with demethylating drugs might sensitize their tumor cells to apoptosis through the restoration of functions of IGSF4 and other pro-apoptotic genes.

\section{Acknowledgments}

We thank Drs. Riccardo Dalla-Favera for the DLBCL cell lines, Renske D.M. Steenbergen for the IGSF4 expression vector and Qiu Guo-hua for some technical help.

\section{References}

1. Kanzler H, Kuppers R, Hansmann ML, Rajewsky K: Hodgkin and Reed-Sternberg cells in Hodgkin's disease represent the outgrowth of a dominant tumor clone derived from (crippled) germinal center B cells. J Exp Med 1996, 184:1495-1505

2. Murray PG, Qiu GH, Fu L, Waites ER, Srivastava G, Heys D, Agathanggelou A, Latif F, Grundy RG, Mann JR, Starczynski J, Crocker J, Parkes SE, Ambinder RF, Young LS, Tao Q: Frequent epigenetic inactivation of the RASSF1A tumor suppressor gene in Hodgkin's lymphoma. Oncogene 2004, 23:1326-1331

3. Baylin SB, Ohm JE: Epigenetic gene silencing in cancer - a mechanism for early oncogenic pathway addiction? Nat Rev Cancer 2006, 6:107-116

4. Jones PA, Baylin SB: The fundamental role of epigenetic events in cancer. Nat Rev Genet 2002, 3:415-428

5. Claus R, Lubbert M: Epigenetic targets in hematopoietic malignancies. Oncogene 2003, 22:6489-6496

6. Suzuki H, Gabrielson E, Chen W, Anbazhagan R, van EM, Weijenberg MP, Herman JG, Baylin SB: A genomic screen for genes upregulated by demethylation and histone deacetylase inhibition in human colorectal cancer. Nat Genet 2002, 31:141-149

7. Yamashita K, Upadhyay S, Osada M, Hoque MO, Xiao Y, Mori M, Sato F, Meltzer SJ, Sidransky D: Pharmacologic unmasking of epigenetically silenced tumor suppressor genes in esophageal squamous cell carcinoma. Cancer Cell 2002, 2:485-495

8. Ying J, Srivastava G, Hsieh WS, Gao Z, Murray P, Liao SK, Ambinder $R$, Tao Q: The stress-responsive gene GADD45G is a functional tumor suppressor, with its response to environmental stresses frequently disrupted epigenetically in multiple tumors. Clin Cancer Res 2005, 11:6442-6449

9. Ying J, Li H, Seng TJ, Langford C, Srivastava G, Tsao SW, Putti T, Murray P, Chan AT, Tao Q: Functional epigenetics identifies a protocadherin PCDH10 as a candidate tumor suppressor for nasopharyngeal, esophageal and multiple other carcinomas with frequent methylation. Oncogene 2006, 25:1070-1080

10. Masuda M, Yageta M, Fukuhara $H$, Kuramochi M, Maruyama $T$, Nomoto A, Murakami Y: The tumor suppressor protein TSLC1 is involved in cell-cell adhesion. J Biol Chem 2002, 277:31014-31019

11. Williams YN, Masuda M, Sakurai-Yageta M, Maruyama T, Shibuya M, Murakami Y: Cell adhesion and prostate tumor-suppressor activity of TSLL2/IGSF4C, an immunoglobulin superfamily molecule homologous to TSLC1/IGSF4. Oncogene 2006, 25:1446-1453

12. Watabe K, Ito A, Koma YI, Kitamura Y: IGSF4: a new intercellular adhesion molecule that is called by three names, TSLC1, SgIGSF and SynCAM, by virtue of its diverse function. Histol Histopathol 2003, 18:1321-1329

13. Kuramochi M, Fukuhara $H$, Nobukuni $T$, Kanbe $T$, Maruyama $T$, Ghosh HP, Pletcher M, Isomura M, Onizuka M, Kitamura T, Sekiya T, Reeves $\mathrm{RH}$, Murakami Y: TSLC1 is a tumor-suppressor gene in human non-small-cell lung cancer. Nat Genet 2001, 27:427-430

14. Zhou L, Jiang W, Ren C, Yin Z, Feng X, Liu W, Tao Q, Yao K: Frequent hypermethylation of RASSF1A and TSLC1, and high viral load of Epstein-Barr Virus DNA in nasopharyngeal carcinoma and matched tumor-adjacent tissues. Neoplasia 2005, 7:809-815

15. Wilting SM, Steenbergen RD, Tijssen M, van Wieringen WN, Helmerhorst TJ, van Kemenade FJ, Bleeker MC, van de Wiel MA, Carvalho B, Meijer GA, YIstra B, Meijer CJ, Snijders PJ: Chromosomal signatures of a subset of high-grade premalignant cervical lesions closely resemble invasive carcinomas. Cancer Res 2009, 69:647-655

16. Steenbergen RD, Kramer D, Braakhuis BJ, Stern PL, Verheijen RH, Meijer CJ, Snijders PJ: TSLC1 gene silencing in cervical cancer cell lines and cervical neoplasia. J Natl Cancer Inst 2004, 96:294-305

17. Fu L, Gao Z, Zhang X, Tsang YH, Goh HK, Geng H, Shimizu N, Tsuchiyama J, Srivastava G, Tao Q: Frequent concomitant epigenetic silencing of the stress-responsive tumor suppressor gene cell adhesion molecule 1, and its interacting partner DAL-1 in nasal NK/T-cell lymphoma. Int J Cancer 2008, 124:1572-1578

18. Masuda M, Kikuchi S, Maruyama T, Sakurai-Yageta M, Williams YN, Ghosh HP, Murakami Y: Tumor suppressor in lung cancer (TSLC)1 suppresses epithelial cell scattering and tubulogenesis. J Biol Chem 2005, 280:42164-42171

19. Reamon-Buettner SM, Borlak J: Epigenetic silencing of cell adhesion 
molecule 1 in different cancer progenitor cells of transgenic c-Myc and c-Raf mouse lung tumors. Cancer Res 2008, 68:7587-7596

20. Yageta $M$, Kuramochi $M$, Masuda M, Fukami $T$, Fukuhara $H$, Maruyama T, Shibuya M, Murakami Y: Direct association of TSLC1 and DAL-1, two distinct tumor suppressor proteins in lung cancer Cancer Res 2002, 62:5129-5133

21. Mayumi M, Sumimoto S, Kanazashi S, Hata D, Yamaoka K, Higaki Y Ishigami T, Kim KM, Heike T, Katamura K: Negative signaling in B cells by surface immunoglobulins. J Allergy Clin Immunol 1996, 98(6 Pt 2):S238-47

22. Mao X, Seidlitz E, Truant R, Hitt M, Ghosh HP: Re-expression of TSLC1 in a non-small-cell lung cancer cell line induces apoptosis and inhibits tumor growth. Oncogene 2004, 23:5632-5642

23. Ying J, Srivastava G, Gao Z, Zhang X, Murray P, Ambinder R, Tao Q: Promoter hypermethylation of the cyclin-dependent kinase inhibitor (CDKI) gene p21WAF1/CIP1/SDI1 is rare in various lymphomas and carcinomas. Blood 2004, 103:743-746

24. Irizarry RA, Bolstad BM, Collin F, Cope LM, Hobbs B, Speed TP Summaries of Affymetrix GeneChip probe level data. Nucleic Acids Res 2003, 31:e15

25. Tusher VG, Tibshirani R, Chu G: Significance analysis of microarrays applied to the ionizing radiation response. Proc Natl Acad Sci USA 2001, 98:5116-5121

26. Storey JD, Tibshirani R: Statistical methods for identifying differentially expressed genes in DNA microarrays. Methods Mol Biol 2003 224:149-157

27. Tao Q, Huang H, Geiman TM, Lim CY, Fu L, Qiu GH, Robertson KD: Defective de novo methylation of viral and cellular DNA sequences in ICF syndrome cells. Hum Mol Genet 2002, 11:2091-2102

28. Lee $\mathrm{KY}$, Geng $\mathrm{H}, \mathrm{Ng} \mathrm{KM}, \mathrm{Yu}$ J, van $\mathrm{HA}$, Cao $\mathrm{Y}$, Zeng $\mathrm{YX}$, Wong $\mathrm{AH}$, Wang X, Ying J, Srivastava G, Lung ML, Wang LD, Kwok TT, Levi BZ, Chan AT, Sung JJ, Tao Q: Epigenetic disruption of interferon-gamma response through silencing the tumor suppressor interferon regulatory factor 8 in nasopharyngeal, esophageal and multiple other carcinomas. Oncogene 2008, 27:5267-5276

29. Yang QW, Liu S, Tian Y, Salwen HR, Chlenski A, Weinstein J, Cohn SL: Methylation-associated silencing of the thrombospondin-1 gene in human neuroblastoma. Cancer Res 2003, 63:6299-6310

30. Lou W, Krill D, Dhir R, Becich MJ, Dong JT, Frierson HF Jr, Isaacs WB, Isaacs JT, Gao AC: Methylation of the CD44 metastasis suppressor gene in human prostate cancer. Cancer Res 1999, 59:2329-2331

31. Yu J, Zhang HY, Ma ZZ, Lu W, Wang YF, Zhu JD: Methylation profiling of twenty four genes and the concordant methylation behaviours of nineteen genes that may contribute to hepatocellular carcinogenesis. Cell Res 2003, 13:319-333

32. Chapman RS, Duff EK, Lourenco PC, Tonner E, Flint DJ, Clarke AR, Watson CJ: A novel role for IRF-1 as a suppressor of apoptosis. Oncogene 2000, 19:6386-6391

33. Hellborg F, Qian W, Mendez-Vidal C, Asker C, Kost-Alimova M, Wilhelm M, Imreh S, Wiman KG: Human wig-1, a p53 target gene that encodes a growth inhibitory zinc finger protein. Oncogene 2001 20:5466-5474

34. Crittenden M, Gough M, Harrington K, Olivier K, Thompson J, Vile RG: Expression of inflammatory chemokines combined with local tumor destruction enhances tumor regression and long-term immunity. Cancer Res 2003, 63:5505-5512

35. Kawakami T, Chano T, Minami K, Okabe H, Okada Y, Okamoto K Imprinted DLK1 is a putative tumor suppressor gene and inactivated by epimutation at the region upstream of GTL2 in human renal cell carcinoma. Hum Mol Genet 2006, 15:821-830

36. Arlt A, Grobe O, Sieke A, Kruse ML, Folsch UR, Schmidt WE, Schafer $\mathrm{H}$ : Expression of the NF-kappa B target gene IEX-1 (p22/PRG1) does not prevent cell death but instead triggers apoptosis in Hela cells. Oncogene 2001, 20:69-76

37. Rouault JP, Rimokh R, Tessa C, Paranhos G, Ffrench M, Duret L, Garoccio M, Germain D, Samarut J, Magaud JP: BTG1, a member of a new family of antiproliferative genes. EMBO J 1992, 11:1663-1670

38. Scholl FA, McLoughlin P, Ehler E, de GC, Schafer BW: DRAL is a p53-responsive gene whose four and a half LIM domain protein product induces apoptosis. J Cell Biol 2000, 151:495-506

39. Beatty J, Terry A, MacDonald J, Gault E, Cevario S, O'Brien SJ, Cameron E, Neil JC: Feline immunodeficiency virus integration in
B-cell lymphoma identifies a candidate tumor suppressor gene on human chromosome 15q15. Cancer Res 2002, 62:7175-7180

40. Kondoh N, Wakatsuki T, Ryo A, Hada A, Aihara T, Horiuchi S, Goseki N, Matsubara O, Takenaka K, Shichita M, Tanaka K, Shuda M, Yamamoto M: Identification and characterization of genes associated with human hepatocellular carcinogenesis. Cancer Res 1999, 59:4990-4996

41. Park K, Kim K, Rho SB, Choi K, Kim D, Oh SH, Park J, Lee SH, Lee JH: Homeobox Msx1 interacts with p53 tumor suppressor and inhibits tumor growth by inducing apoptosis. Cancer Res 2005, 65:749-757

42. Gabellini D, Colaluca IN, Vodermaier HC, Biamonti G, Giacca M, Falaschi A, Riva S, Peverali FA: Early mitotic degradation of the homeoprotein $\mathrm{HOXC10}$ is potentially linked to cell cycle progression. EMBO J 2003, 22:3715-3724

43. Sanjo H, Kawai T, Akira S: DRAKs, novel serine/threonine kinases related to death-associated protein kinase that trigger apoptosis J Biol Chem 1998, 273:29066-29071

44. Suzuki M, Toyooka S, Shivapurkar N, Shigematsu H, Miyajima K, Takahashi T, Stastny V, Zern AL, Fujisawa T, Pass HI, Carbone M, Gazdar AF: Aberrant methylation profile of human malignant mesotheliomas and its relationship to SV40 infection. Oncogene 2005, 24:1302-1308

45. Yoshida Y, Nakamura T, Komoda M, Satoh H, Suzuki T, Tsuzuku JK, Miyasaka T, Yoshida EH, Umemori H, Kunisaki RK, Tani K, Ishii S, Mori S, Suganuma M, Noda T, Yamamoto T: Mice lacking a transcriptional corepressor Tob are predisposed to cancer. Genes Dev 2003, 17:1201-1206

46. Drivdahl R, Haugk KH, Sprenger CC, Nelson PS, Tennant MK, Plymate SR: Suppression of growth and tumorigenicity in the prostate tumor cell line M12 by overexpression of the transcription factor SOX9. Oncogene 2004, 23:4584-4593

47. Kataoka K, Yoshitomo-Nakagawa K, Shioda S, Nishizawa M: A set of Hox proteins interact with the Maf oncoprotein to inhibit its DNA binding, transactivation, and transforming activities. J Biol Chem 2001, 276:819-826

48. Reeves HL, Narla G, Ogunbiyi O, Haq Al, Katz A, Benzeno S, Hod E, Harpaz N, Goldberg S, Tal-Kremer S, Eng FJ, Arthur MJ, Martignetti JA, Friedman SL: Kruppel-like factor 6 (KLF6) is a tumor-suppressor gene frequently inactivated in colorectal cancer. Gastroenterology 2004, 126:1090-1103

49. Uchino K, Ito A, Wakayama T, Koma Y, Okada T, Ohbayashi C, Iseki S, Kitamura Y, Tsubota N, Okita Y, Okada M: Clinical implication and prognostic significance of the tumor suppressor TSLC1 gene detected in adenocarcinoma of the lung. Cancer 2003, 98:1002-1007

50. Furuno $\mathrm{T}$, Ito A, Koma $\mathrm{Y}$, Watabe K, Yokozaki H, Bienenstock J, Nakanishi M, Kitamura Y: The spermatogenic Ig superfamily/synaptic cell adhesion molecule mast-cell adhesion molecule promotes interaction with nerves. J Immunol 2005, 174:6934-6942

51. Shen L, Kondo Y, Guo Y, Zhang J, Zhang L, Ahmed S, Shu J, Chen $X$, Waterland RA, Issa JP: Genome-wide profiling of DNA methylation reveals a class of normally methylated CpG island promoters. PLoS Genet 2007, 3:2023-2036

52. Karpf AR, Jones DA: Reactivating the expression of methylation silenced genes in human cancer. Oncogene 2002, 21:5496-5503

53. Karpf AR, Peterson PW, Rawlins JT, Dalley BK, Yang Q, Albertsen H, Jones DA: Inhibition of DNA methyltransferase stimulates the expression of signal transducer and activator of transcription 1, 2, and 3 genes in colon tumor cells. Proc Natl Acad Sci USA 1999, 96 14007-14012

54. Garcia JF, Villuendas R, Algara P, Saez Al, Sanchez-Verde L, MartinezMontero JC, Martinez P, Piris MA: Loss of p16 protein expression associated with methylation of the p16INK4A gene is a frequent finding in Hodgkin's disease. Lab Invest 1999, 79:1453-1459

55. Garcia MJ, Martinez-Delgado B, Cebrian A, Martinez A, Benitez J, Rivas C: Different incidence and pattern of p15INK4b and p16INK4a promoter region hypermethylation in Hodgkin's and CD30-Positive non-Hodgkin's lymphomas. Am J Pathol 2002, 161:1007-1013

56. Sanchez-Aguilera A, Delgado J, Camacho FI, Sanchez-Beato M Sanchez L, Montalban C, Fresno MF, Martin C, Piris MA, Garcia JF: Silencing of the p18INK4c gene by promoter hypermethylation in Reed-Sternberg cells in Hodgkin lymphomas. Blood 2004, 103:2351-2357 